(RESEARCH ARTICLE)

\title{
Ethnobotanical study and effect on mice weight gain of four plants used during famine in Burkina Faso: Raphionacme daronii, Gardenia erubescens, Leptadenia hastata and Balanites aegyptiaca
}

\author{
Paré Dramane *, Hilou Adama, N'do Jotham Yhi-pênê, Guenne Samson and Nacoulma Odile Germaine

\begin{abstract}
Laboratory of Biochemistry and Applied Chemistry (LABIOCA), UFR/SVT, 09 BP 848, Ouagadougou 09, University of
\end{abstract} \\ Ouagadougou, Burkina Faso.
}

Publication history: Received on 15 August 2019; revised on 06 September 2019; accepted on 26 September 2019

Article DOI: https://doi.org/10.30574/wjarr.2019.3.2.0051

\begin{abstract}
Overweight and obesity are pathologies that increase dramatically, they are most often associated with diseases such as hypertension, heart failure, stroke, type II diabetes, insulin resistance, dyslipidemias, certain cancers etc .The objective was to conduct an ethnobotanical survey of 4 plants consumed during periods of hunger and to determine the effect of the extracts of these plants on weight gain and food intake.The survey was based on direct dialogue using the respondent's choice language and the use of a questionnaire. Acute toxicity was determined on NMRI mice by orally administering of single dose of $2000 \mathrm{mg} / \mathrm{kg}$. The slimming and anorectic potential of plant extracts was to evaluate the effect of plant extracts on weight gain and food intake of animals treated at 50, 100 and $500 \mathrm{mg} / \mathrm{kg}$. 55 person with an age between 40 and 81 years old were interviewed. Raphionacme daronii gave the highest frequency of citation with $25.42 \%$. All plant species showed no toxicity at $2000 \mathrm{mg} / \mathrm{kg}$. Gardenia erubescens at $50 \mathrm{mg} / \mathrm{kg}$ gave a good activity on weight gain with a reduction of $5.18 \%$ against the control with an increase of $11.02 \%$. Gardenia erubescens at $500 \mathrm{mg} / \mathrm{kg}$ gave the best anorectic activity on the treated animals.These plant extracts are an asset in the search for a new natural and less toxic molecule for the fight against obesity.
\end{abstract}

Keywords: Overweight; Ethnobotanical survey; Food intake; Gardenia erubescens

\section{Introduction}

Obesity, called a global epidemic by the World Health Organization (WHO), has indeed multiple harmful effects as well on the sanitary level as economic and human. In fact, obesity is a serious public health problem throughout the world. It is a risk factor for various chronic health conditions such as cardiovascular disease, type 2 diabetes and some cancers [1]. These diseases not only lead to a decline in quality of life because of their chronic nature, they also lead to serious complications and premature death [2]. To remedy this, several means are used such as physical exercises, dietetics, surgical treatments, pharmaceutical drugs, herbal medicine, etc....

Plants have always been the main source (up to 90\%) of drugs or care for the treatment of various pathologies of the population in many African countries [3]. Burkina Faso, like Sahelian countries, has often been confronted in times of famine [4]. During these periods of food shortage, people usually resort to plants that have appetite suppressant effects. These provide them with satiety, usually without significant energy, which can lead to weight loss. So taking a supplement of these appetite suppressants may help you lose weight by reducing appetite and cravings. The activity of these plant species is certainly related to the presence of metabolites such as glycosilated pregnanes [5], mannans [6], caffeine $[7,8]$, mucilage, phenylalanine $[9,10]$, which can cause anorexia, reduce triglycerides or inhibit the enzymes involved in lipid metabolism such as pancreatic lipase, lipoprotein lipase and glycerophosphate dehydrogenase or to increase energy expenditure. All these mechanisms result in a reduction of fat mass and thus body weight.

\footnotetext{
${ }^{*}$ Corresponding author

E-mail address: paredra@yahoo.fr
} 
Raphionacme daronii, Gardenia erubescens, Leptadenia hastata, Balanites aegyptiaca are four (4) plants consumed during periods of scarcity. The fruits of Gardenia erubescens contain carbohydrates, fibers [11], they are also rich in anthraquinones, tannins, sterols and triterpenes [12]. The tuber of Raphionacme daronii contains sugars and starch [13]. Leptadenia hastata (Pers.) Decne contains glucosides, steroidal saponins, triterpenes, flavonoids, mucilage, sterols, tannins [14]. Phytochemical investigations carried out on B. aegyptiaca revealed the presence of several classes of secondary metabolites such as flavonoids [15], coumarins [16], steroidal saponosides [17].As part of this study, the objective was to conduct an ethnobotanical survey on these plants and to determine the effect of the extracts of these plants on weight gain and food intake of animals.

\section{Material and methods}

\subsection{Ethnobotanical survey}

The surveys were conducted in the two provinces of Burkina Faso where there are traditherapeutes, nomadic populations or hunters during the period from September to October 2016. The survey was conducted on four (4) species of plants frequently used during periods of famine, namely, Raphionacme daronii, Gardenia erubescens, Leptadenia hastata, Balanites aegyptiaca. The approach was based on a dialogue using the respondent's choice language and the use of a questionnaire. A field trip was organized and the plants mentioned in the interview were collected with the help of the respondent. The survey data were processed by Excel software and plant quotations frequencies calculated using the following formula:

$$
\mathrm{F}=\frac{\text { person who cited the plant specie }}{\text { total person interviewed }} \times 100
$$

\subsection{Biological material}

The fruits of Gardenia erubescens, Balanites aegyptiaca, leaves of Leptadenia hastata and tubers of Raphionacme daronii were harvested in Toma (northwestern Burkina Faso) and Dori (northeastern Burkina Faso) during the growing season (October 2016). The species were authenticated by Professor Millogo R. Jeanne, botanist at the University of Ouagadougou. The samples were dried under laboratory conditions, sheltered from the sun, then pulverized and stored in freezer bags for different extractions. The fruit and tuber pulps were kept in the freezer.

Male and female mice (NMRI) from the pet shop at the University of Ouagadougou ; Burkina Faso were acclimated for one week $\left(25^{\circ} \mathrm{C}\right.$ with a circadian cycle) for various in vivo tests.

\subsection{Extraction}

The samples were extracted by ethanolic maceration, so $50 \mathrm{~g}$ of Leptadenia hastata leaves powder were extracted in $500 \mathrm{ml}$ of pure ethanol. For Gardenia erubescens, Balanites aegyptiaca, Raphionacme daronii; the fruit and tuber pulps previously stored in the freezer were milled, then $50 \mathrm{~g}$ of the ground material of each sample is placed in $500 \mathrm{ml}$ of pure ethanol. These different mixtures obtained were stirred for 24 hours. The extracts obtained are concentrated using a rotary evaporator equipped with a vacuum pump. The concentrate was dried in an oven and kept for carrying out the different tests.

\subsection{Assessment of the acute toxicity of plant extracts}

Acute toxicity was determined according to the method described by OECD [18]. The animals are fasted for 12 hours, then the weight of each mouse is taken and they receive a single dose of extract ( $2000 \mathrm{mg} / \mathrm{kg}$ of body weight). The extracts were administered orally by gavage to the different test batch against a control batch that received only water. The signs of toxicity (writhing, panic, moribund state, death ...) were noted by group after $2 \mathrm{~h}, 24 \mathrm{~h}, 48 \mathrm{~h}, 72 \mathrm{~h}$ and the animals are kept under observation for two weeks.

\subsection{Slimming and anorectic potential of plant extracts}

It consisted of evaluating the effect of plant extracts on weight gain and food intake of treated animals. The study used the method described by Van Heerden and al. [5].

\subsubsection{Animal treatment}

The study uses mice aged 5-6 weeks. The mice are divided into four (4) groups of six (6) mice each. These group received doses of 50,100 and $500 \mathrm{mg} / \mathrm{kg}$ body weight of an extract preparation that was administered daily to the animals orally 
and the negative control group that received only the vehicle (water). The mice are placed 12 hours in the light, 12 hours in the dark and have free access to food and water. They were treated for a period of 4 weeks.

Group 1: Gavage with water

Group 2 : Gavage with plant extracts at $50 \mathrm{mg} / \mathrm{kg}$ body weight

Group 3: Gavage with plant extracts at $100 \mathrm{mg} / \mathrm{kg}$ body weight

Group 4: Gavage with plant extracts at $500 \mathrm{mg} / \mathrm{kg}$ body weight

Composition of animal food

Protein (26\%), corn starch (50\%), sucrose (9\%), soybean oil (5\%), cellulose (5\%), mineral mixture and vitamin (5\%).

\subsubsection{Slimming potential (weight gain)}

It consisted in determining the effect of the extract on the weight of the treated animals. During the experience period, the body weight of each animal was measured every three days using a standard weighing device. The net weight gain was calculated: Net weight gain = final weight - initial weight.

\subsubsection{Anorectic activity of the extract (food intake)}

It consisted of determining the effect of the extract on the amount of food taken from the animals. The aim was to measure the total amount of food remaining per weigh each day for each batch. Food consumption $=$ total amount of food given - amount of food remaining.

\section{Results}

\subsection{Ethnobotanical survey}

During the survey we interviewed 55 people between the ages of 40 and 81 years old; more than $50 \%$ of whom are between 50 and 70 years old. The number of years of practice experience varies between 7 and 35 years. Men accounted for $92.72 \%$ of our respondents compared to $07.27 \%$ of women and they were traditional healers, herbalists, hunters and certain person with knowledge of plants. Raphionacme daronii gave the highest frequency of citation (Table 1).

Table 1 Results of ethnobotanical survey

\begin{tabular}{|c|c|c|c|c|c|c|}
\hline & local name & Frequency & Part used & Indication & Mode of use & Other use \\
\hline $\begin{array}{l}\text { Raphionacme } \\
\text { daronii }\end{array}$ & Goin & $25.42 \%$ & Tuber & $\begin{array}{l}\text { Against } \\
\text { hunger }\end{array}$ & $\begin{array}{l}\text { Raw } \\
\text { consumption } \\
\text { of tubers }\end{array}$ & $\begin{array}{l}\text { Tubers are used } \\
\text { against thirst } \\
\text { Sexual impotence }\end{array}$ \\
\hline $\begin{array}{l}\text { Gardenia } \\
\text { erubescens }\end{array}$ & $\begin{array}{l}\text { Kouin or } \\
\text { Souboudga }\end{array}$ & $20.34 \%$ & Fruits & $\begin{array}{l}\text { Against } \\
\text { hunger }\end{array}$ & $\begin{array}{l}\text { Raw } \\
\text { consumption } \\
\text { of tubers }\end{array}$ & $\begin{array}{l}\text { The bark is used } \\
\text { against yellow fever, } \\
\text { stomach ache }\end{array}$ \\
\hline $\begin{array}{l}\text { Leptadenia } \\
\text { hastata }\end{array}$ & $\begin{array}{l}\text { Toun or } \\
\text { Tatola or } \\
\text { Belongo }\end{array}$ & $10.16 \%$ & Leaves & $\begin{array}{l}\text { Against } \\
\text { hunger }\end{array}$ & $\begin{array}{l}\text { Raw } \\
\text { consumption } \\
\text { of tubers }\end{array}$ & $\begin{array}{l}\text { The leaves are used } \\
\text { against thirst, } \\
\text { diarrhea, cough, } \\
\text { infertility }\end{array}$ \\
\hline $\begin{array}{l}\text { Balanites } \\
\text { aegytiaca }\end{array}$ & $\begin{array}{l}\text { Tanèè } \\
\text { sinbèlè }\end{array}$ & $10.16 \%$ & Fruits & $\begin{array}{l}\text { Against } \\
\text { hunger }\end{array}$ & $\begin{array}{l}\text { Raw } \\
\text { consumption } \\
\text { of tubers }\end{array}$ & $\begin{array}{l}\text { Fruits are eaten to } \\
\text { fight against stomach } \\
\text { ache The bark is used } \\
\text { against malaria and } \\
\text { scorpion bites }\end{array}$ \\
\hline
\end{tabular}

\subsection{Acute toxicity}

Oral gavage was the method of administering the extracts of the four (04) plants used. On batches of six (06) mice we did not observe any mortality or signs of intoxication after seventy two hours (72 h) of observation following the administration of the extracts (Table 2). 
Table 2 Results of plants toxicity

\begin{tabular}{|c|c|c|c|c|c|c|c|c|}
\hline \multirow[t]{2}{*}{ Plants } & \multirow[t]{2}{*}{ Dose } & \multirow{2}{*}{$\begin{array}{l}\text { Number of } \\
\text { Mice uses }\end{array}$} & \multicolumn{6}{|c|}{ Number of deaths after } \\
\hline & & & $2 \mathbf{h}$ & $24 h$ & $48 h$ & $72 \mathrm{~h}$ & $\begin{array}{l}\% \text { of death } \\
\text { after } 72 \mathrm{~h}\end{array}$ & $\begin{array}{l}\text { Signs } \\
\text { toxicity }\end{array}$ \\
\hline $\begin{array}{l}\text { Raphionacme } \\
\text { daronii }\end{array}$ & $\begin{array}{l}2000 \\
\mathrm{mg} / \mathrm{kg} \cdot \mathrm{bw}\end{array}$ & 06 & 00 & 00 & 00 & 00 & 00 & $\begin{array}{l}\text { No sign of } \\
\text { toxicity }\end{array}$ \\
\hline $\begin{array}{l}\text { Gardenia } \\
\text { erubescens }\end{array}$ & $\begin{array}{l}2000 \\
\mathrm{mg} / \mathrm{kg} \cdot \mathrm{bw}\end{array}$ & 06 & 00 & 00 & 00 & 00 & 00 & $\begin{array}{l}\text { No sign of } \\
\text { toxicity }\end{array}$ \\
\hline $\begin{array}{l}\text { Leptadenia } \\
\text { hastata }\end{array}$ & $\begin{array}{l}2000 \\
\mathrm{mg} / \mathrm{kg} \cdot \mathrm{bw}\end{array}$ & 06 & 00 & 00 & 00 & 00 & 00 & $\begin{array}{l}\text { No sign of } \\
\text { toxicity }\end{array}$ \\
\hline $\begin{array}{l}\text { Balanites } \\
\text { aegyptiaca }\end{array}$ & $\begin{array}{l}2000 \\
\mathrm{mg} / \mathrm{kg} \cdot \mathrm{bw}\end{array}$ & 06 & 00 & 00 & 00 & 00 & 00 & $\begin{array}{l}\text { No sign of } \\
\text { toxicity }\end{array}$ \\
\hline
\end{tabular}

\subsection{Effect of extracts on the weight of treated animals}

Figure 1,2,3,4 shows the effect of Leptadenia Hastata, Balanites aegyptiaca, Raphionacme daronii and Gardenia erubescens on the weight of animals treated at 50,100 and $500 \mathrm{mg} / \mathrm{kg}$ bw. The weight in control animals is increasing throughout the experiment. Leptadenia hastata at $50 \mathrm{mg} / \mathrm{kg}$ caused a weight reduction of the treated animals compared to the control group at doses of 100 and $500 \mathrm{mg} / \mathrm{kg}$. Balanites aegyptiaca at $500 \mathrm{mg} / \mathrm{kg}$ reduces the weight of the animals as shown by the shape of the curve (fig 2). Weight in control animals is increasing throughout treatment. At the end of the experiment the $500 \mathrm{mg} / \mathrm{kg}$ extract reduced the weight by $0.8 \%$ compared to the initial weight (Fig. 5 (2)) while the control gave a growth of $11.02 \%$. For Raphionacme daronii extract, the $100 \mathrm{mg} / \mathrm{kg}$ weight dose exhibited the best activity with a weight reduction of 3.91\% compared to a 5.83\% increase in the control (Fig 6 (1)). Extract at 50 and 500 $\mathrm{mg} / \mathrm{kg}$ showed good activity compared to the control. For Gardenia erubescens extract the best activity was obtained with the dose of $50 \mathrm{mg} / \mathrm{kg}$. At this dose it causes a reduction of 5.18\% (Fig. 6 (2)). The $500 \mathrm{mg} / \mathrm{kg}$ extract also causes weight reduction in the treated animals.
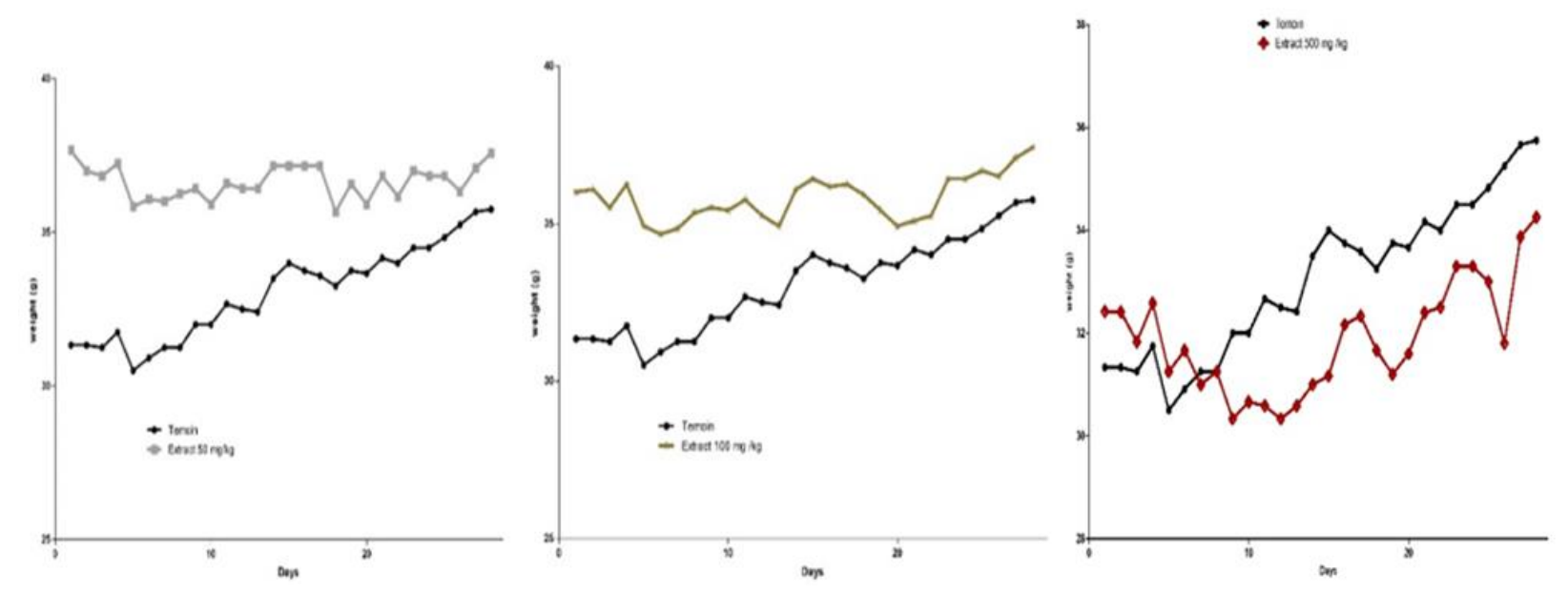

Figure 1 Effect of Leptadenia hastata extracts on the weight of treated animals 

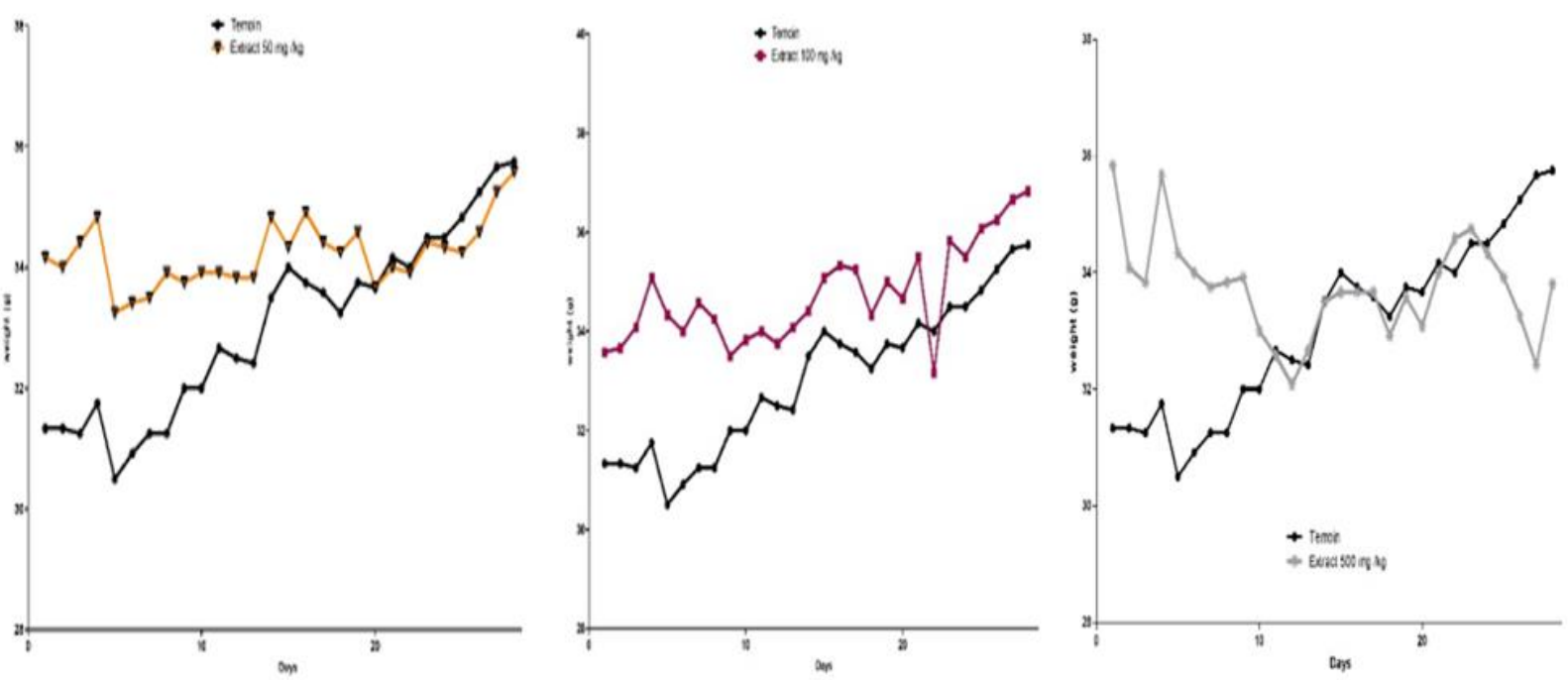

Figure 2 Effect of Balanites aegyptiaca on the weight of animals
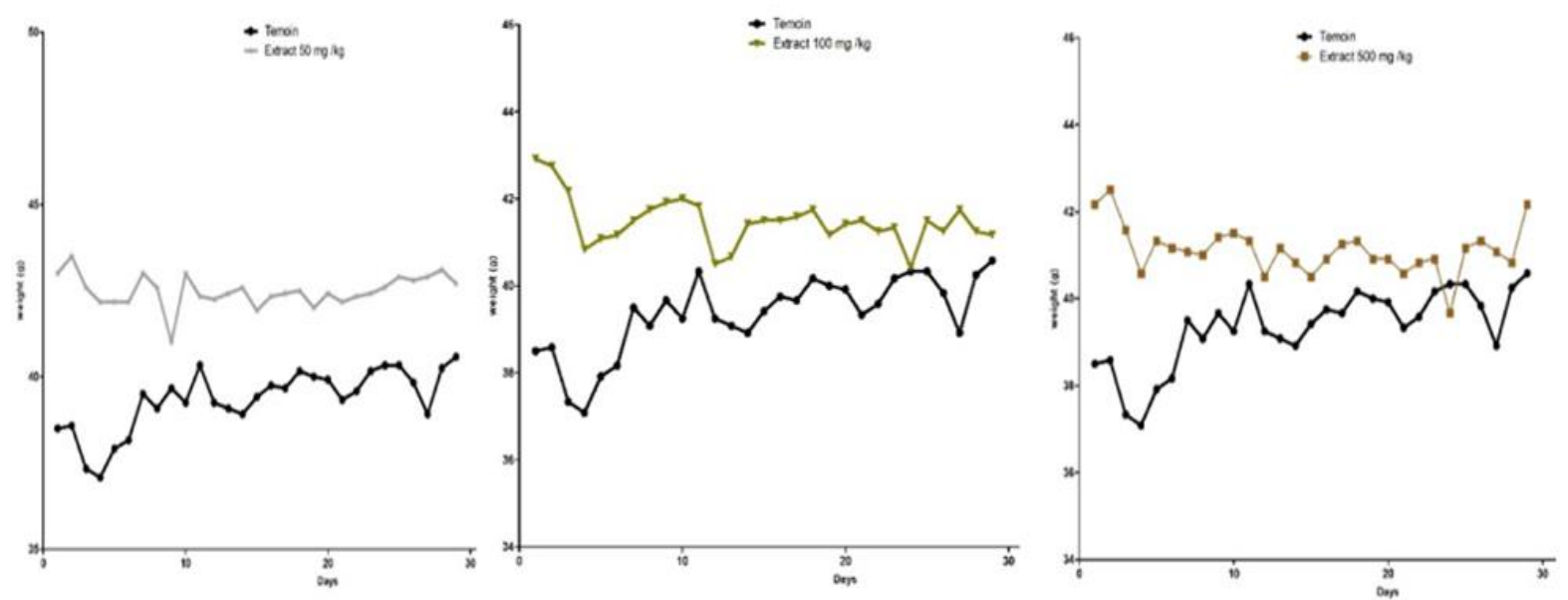

Figure 3 Effect of Raphionacme daronii on the weight of animals
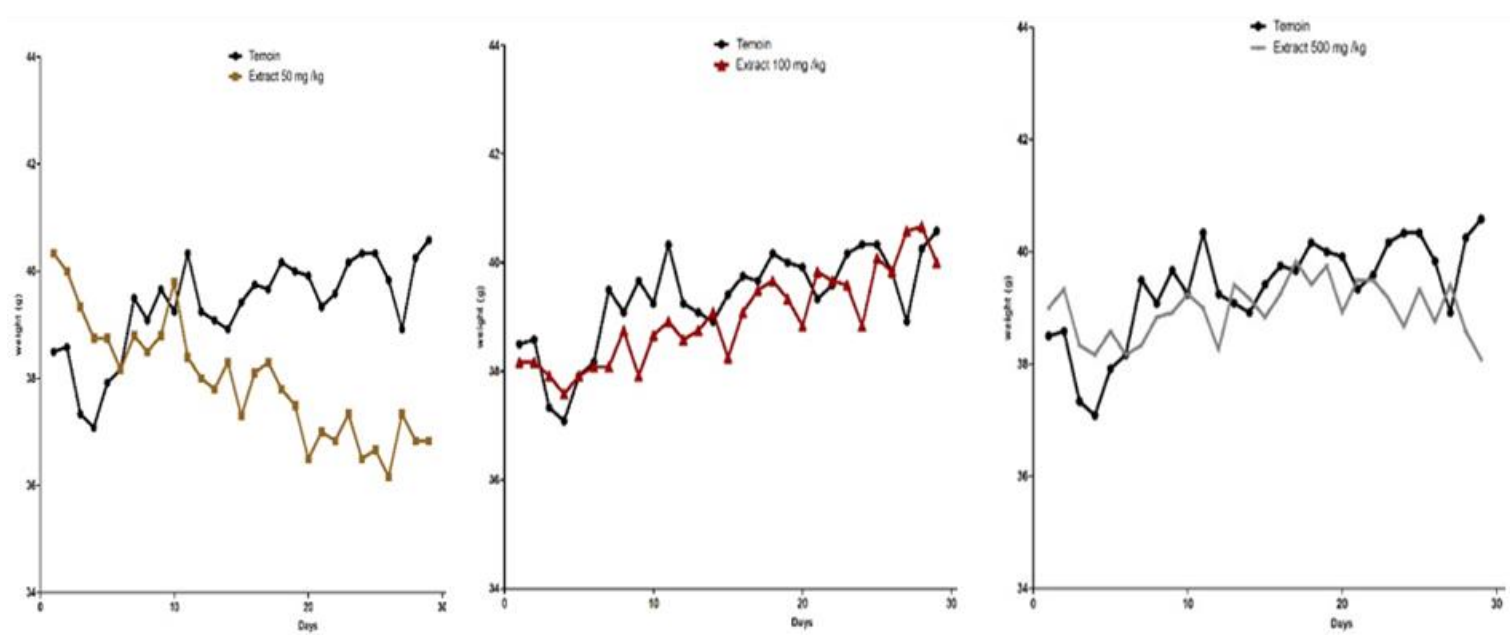

Figure 4 Effect of Gardenia erubescens on the weight of animals 


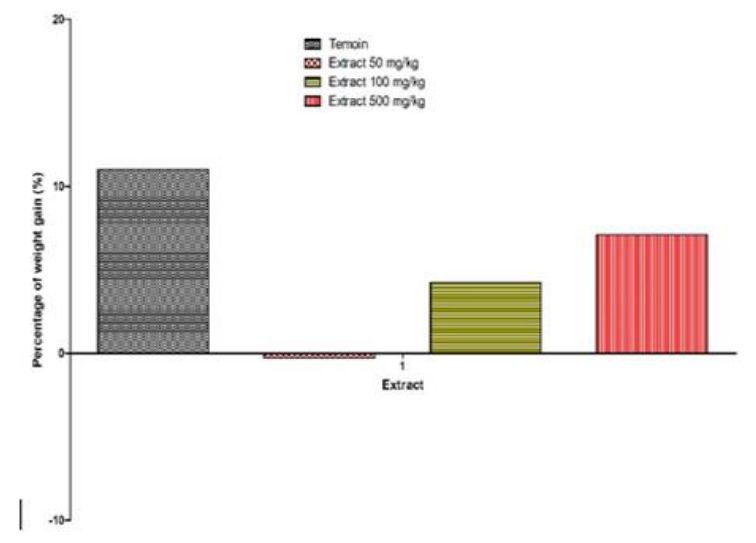

1

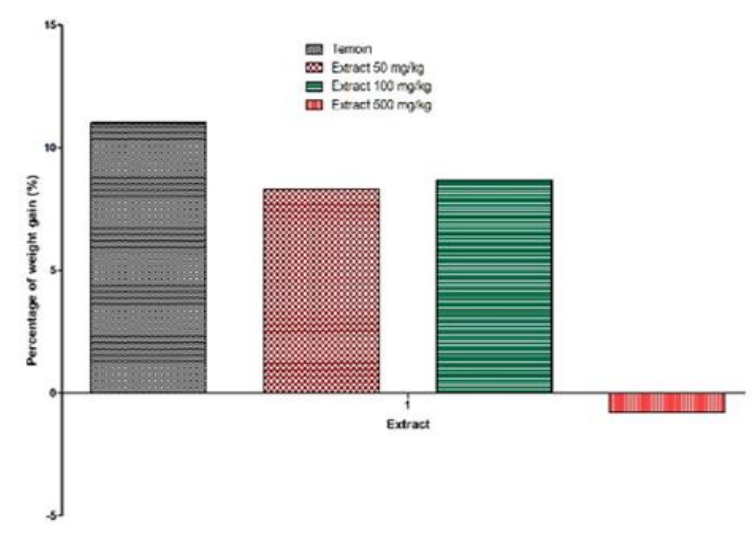

2

Figure 5 Weight reduction percentage of Leptadenia hastata (1) and Balanites aegyptiaca (2) extracts

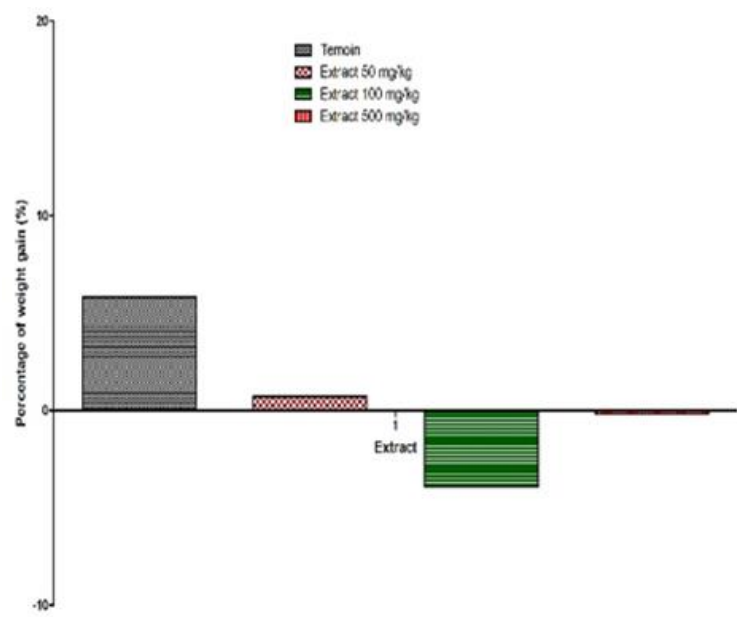

1

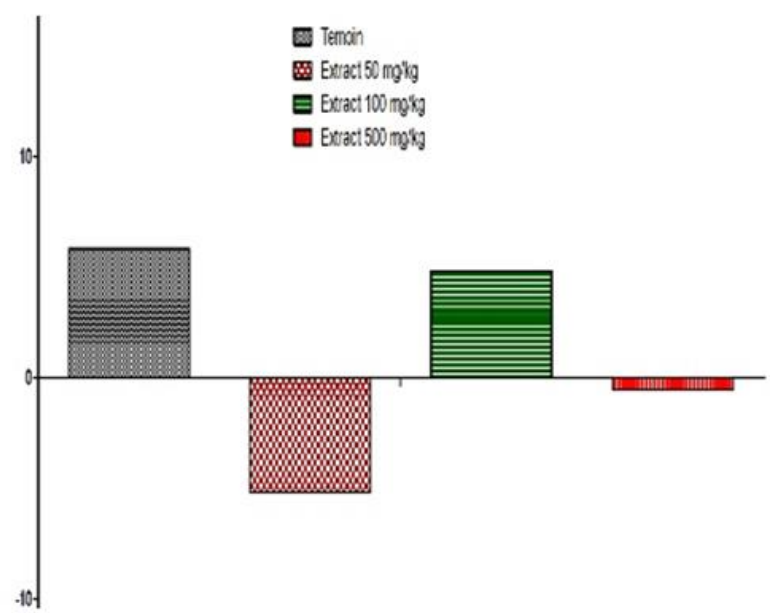

2

Figure 6 Weight reduction percentage of Raphionacme daronii (1) and Gardenia erubescens (2) extracts

\subsection{Anorectic effect of animal extracts}

Figure 7 shows the effect of extracts of Leptadenia hastata, Balanites aegyptiaca, Raphionacme daronii and Gardenia erubescens respectively. The administration of Leptadenia hastata extract at 50,100 and $500 \mathrm{mg} / \mathrm{kg}$ to the animals caused a reduction in food intake compared with the control which showed an increase in food intake. The extract at 50 and $100 \mathrm{mg} / \mathrm{kg}$ gave the best activities. With regard to Balanites aegyptiaca extract, the $100 \mathrm{mg} / \mathrm{kg}$ dose gave the best activity compared to the control group and those receiving 50 and $500 \mathrm{mg} / \mathrm{kg}$ body weight. Raphionacme daronii extract at 50 and $100 \mathrm{mg} / \mathrm{kg}$ had no effect on the amount of food taken, unlike the $500 \mathrm{mg} / \mathrm{kg}$ extract which caused a significantly different reduction in food intake than witness. Gardenia erubescens at $500 \mathrm{mg} / \mathrm{kg}$ gave the best activity on Food intake reduction. 


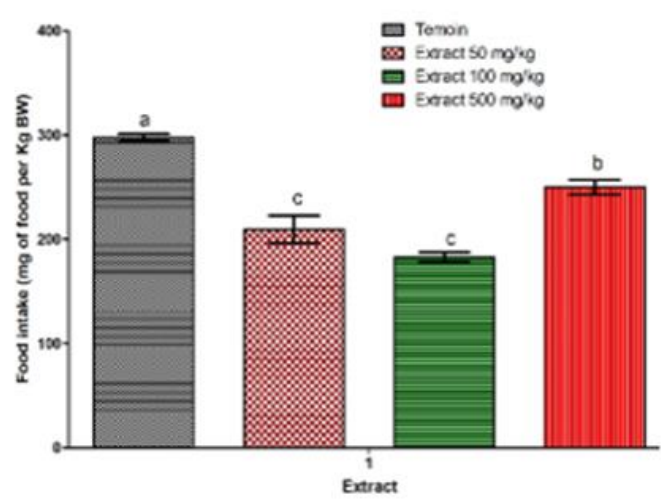

1

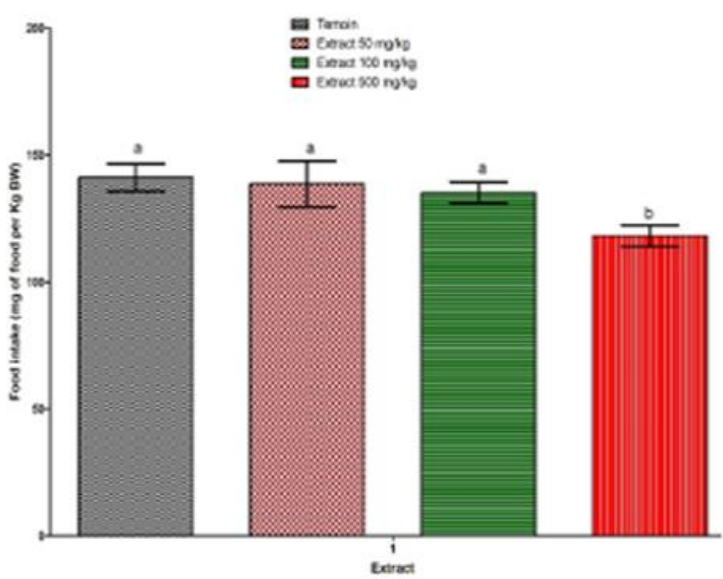

3

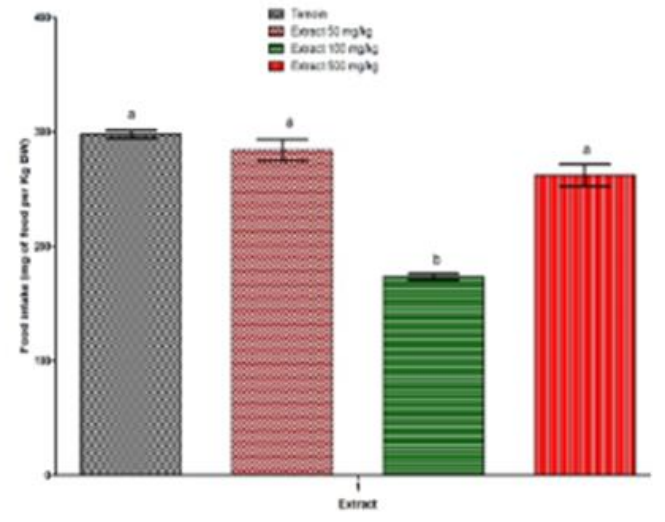

2

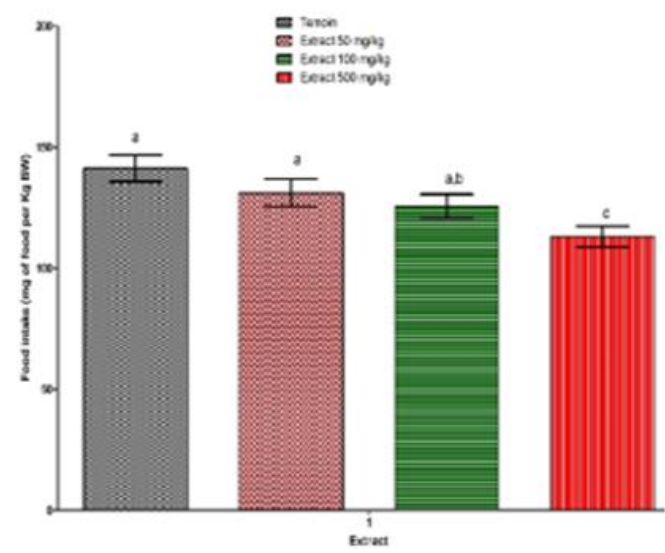

4

Figure 7 Food consumption per kg of body weight of treated animals (1=Leptadenia hastata, 2=Balanites aegyptiaca, $3=$ Raphionacme daronii, 4=Gardenia erubescens) Values are expressed as mean + S.D. Means with different letters in a row differ significantly $(\mathrm{P}>0.05)$

\section{Discussion}

The 4 species of plants namely Leptadenia hastata, Balanites aegyptiaca, Raphionacme daronii and Gardenia erubescens are all used in Burkina Faso during periods of famine. Raphionacme daronii gave the highest frequency of use. MillogoRasolodimby et al. [19] also found during their ethnobotanical surveys that leaves of Leptadenia hastata, young leaves and fruits of Balanites aegyptiaca are species of starvation plants consumed in Burkina Faso. Diarra et al. [20] have shown in their ethnobotanical study conducted in Mali that the fruits of Gardenia erubescens and the tuber Raphionacme daronii are used during the lean periods.

Administration of the ethanolic extracts of plant species to $2000 \mathrm{mg} / \mathrm{kg}$ body weight in mice showed no signs of toxicity. According to the OECD [18] these extracts are very low in toxicity. This could explain the consumption of these species by the populations. Bayala et al. [21] found that Leptadenia hastata is not toxic up to $4000 \mathrm{mg} / \mathrm{kg}$. Our results corroborate those of Suky et al. [22] who also showed that Balanites aegyptiaca showed no toxicity at $2000 \mathrm{mg} / \mathrm{kg}$.

Gardenia erubescens at $50 \mathrm{mg} / \mathrm{kg}$ gave the best activity among the extracts of the 4 plants on weight reduction. This good activity could be explained by the presence of sterols and triterpenes [12]. Certain molecules such as ursolic acid, a pentacyclic triterpene of Sambucus australis reduces abdominal adipogenesis in obese mice [23]. The extract is not dependent dose, the activity at $50 \mathrm{mg} / \mathrm{kg}$ of the extract is greater than that of 100 and $500 \mathrm{mg} / \mathrm{kg}$, this could be explained by the presence of an effective dose which is $50 \mathrm{mg} / \mathrm{kg}$. The other three extracts showed a good weight reduction compared to the control. Leptadenia hastata is rich in glucosides, steroidal saponins, triterpenes, flavonoids [14]. Balanites aegyptiaca have demonstrated the presence of several classes of secondary metabolites such as flavonoids [15], coumarins [16], steroidal saponosides [17]. Flavonoids in the extracts may explain the reducing effect of weight in treated animals. Some flavonoids are known to reduce obesity. Resveratrol (Stilbenoid) and genistein (Isoflavone) 
produce a reduction in weight by their adipocytes apoptosis inducing action [24]. Rutin, quercetin, naregenine inhibit the activity of glycerol-3-phosphate dehydrogenase (GPDH) and the expression of genes involved in the differentiation of adipocytes, thus preventing their proliferation [25]. Thus causes a reduction in weight.

Extracts of Leptadenia hastata at 50,100,500 mg/kg, Balanites aegyptiaca at 100, $500 \mathrm{mg} / \mathrm{kg}$, Raphionacme daronii at $500 \mathrm{mg} / \mathrm{kg}$ and Gardenia erubescens at $100,500 \mathrm{mg} / \mathrm{kg}$ showed an anorectic effect compared with witness. Aquino et al. [26] isolated polyoxypregnanes in the extract of Leptadenia hastata, also five glycosylated steroids were isolated from Balanites aegyptiaca fruits by Farid et al. [27]. Triterpenes and flavonoids were highlighted in the extract of Balanites aegyptiaca.

The anorexigenic activity observed in plant extracts is due to the presence of a compound such as glycosylated pregnanes and flavonoids. At present, the glycosilic pregnans isolated in Hoodia gordonii have an action in the central nervous system. It would mimic the effects of glucose on the hypothalamus, which would then send messages of satiety to the body. The molecule would have an action ten thousand times greater than that of glucose without bringing any calorie [28]. Triterpenes could also inhibit the secretion of ghrelin hormone orexigen and reduce food intake [29].

\section{Conclusion}

In conclusion the results of our study indicated that Leptadenia hastata, Balanites aegyptiaca, Raphionacme daronii and Gardenia erubescens are used in Burkina Faso against hunger in times of scarcity. The extracts of these plants are not toxic and they have an effect on the reduction of weight gain and food intake. These plant extracts are an asset in the search for a new natural and less toxic molecule for the fight against obesity. They could help to regulate weight gain in people with obesity that is gaining momentum in developing countries.

\section{Compliance with ethical standards}

\section{Acknowledgments}

This work was supported by Laboratory of Biochemistry and Applied Chemistry in Burkina Faso. Special thanks to Research Institute for Health Sciences (IRSS) for the studies in vivo

\section{Disclosure of conflict of interest}

Authors have declared that no competing interests exist.

\section{Statement of ethical approval}

All experimental animal protocols had complied with the instructions of the Institutional Animal Ethics Committee (directive 2010/63/EU on protection of animals used for scientific purposes). Ethical approval code: 2010/63/EU, Date of approval: 20 October 2010. The institutional animal ethical guidelines were strictly observed. All authors hereby declare that "Principles of laboratory animal care were followed, as well as specific national laws where applicable.

\section{References}

[1] Asfaw A. (2006). The effects of obesity on doctor-diagnosed chronic diseases in Africa: Empirical results from Senegal and South Africa. J Public Health Policy, 27, 250-64.

[2] Adams KF, Schatzkin A, Harris TB, Kipnis V, Mouw T, Ballard-Barbash R, Hollenbeck A, and Leitzmann MF. (2006). Overweight, obesity, and mortality in a large prospective cohort of persons 50 to 71 years old. N Engl J Med, 355, 763-78.

[3] Tchamadeu MC, Dzeufiet PDD, Nouga CCK, Azebaze AGB, Allard JP, Girolami IT, Kamtchouing P and Dimo T. (2010). Hypoglycaemic effects of Mammea africana (Guttiferae) in diabetic rats. Journal of Ethnopharmacology, $127,368-372$.

[4] Millogo R. (2001). Man, climate, and plant food resources in times of subsistence crisis during the 20th century in Burkina Faso. PHD. thesis, university of Ouagadougou, Burkina Faso, 211.

[5] Van Heerden FR. (2008). Hoodia gordonii: A natural appetite suppressant. Journal of Ethnopharmacology, 119, 434-437. 
[6] Vasques CA, Rossetto S, Halmenschlager G, Linden R, Heckler E, Fernandez MS and Alonso JL. (2008). Evaluation of the pharmacotherapeutic efficacy of Garcinia cambogia plus Amorphophallus konjac for the treatment of obesity. Phytotherapy Research, 22(9), 1135-40.

[7] Parveen K. (2011). Herbal fight for obesity. International Journal of Parmaceutical Research of Development, 3(4), 193-201.

[8] Guodong Z, Kazutoshi S, Tsutomu 0, Lekh RJ and Itaro 0. (2004). Anti-obesity effects of three major compo nents of green tea, catechins, caffeine and theanine, in mice. In Vivo, 18, 55-62.

[9] Dimitri T. (2010). Obesity: recent discoveries of molecular mechanisms behind new therapeutic strategies. PHD. thesis, Université Henri Poincare - Nancy 1, 79.

[10] Halford J. (2005). Serotonin (5-HT) drugs: effects on appetite expression and use for the treatment of obesity. Curr Drug Targets, 6(2), 201-13.

[11] Bello MO, Falade OS, Adewusi SRA and Olawore NO. (2008). Studies on the chemical compositions and antinutrients of some lesser known Nigeria fruits. African Journal of Biotechnology, 7(21), 3972-3979.

[12] Kini F, Saba A, Ouedraogo S, Tingueri B, Sanou G and Guissou IP. (2008). Nutritional and therapeutic potential of some "wild" fruit species of burkina faso. African Pharmacopoeia and Traditional Medicine, 15, 32-35.

[13] Grubben GJH. (2004). Vegetables.PROTA, 737.

[14] Nacoulma 0. (1996). Medicinal plants and traditional medical practices in Burkina Faso. Case of the central plateau, TOME I. Thesis, University of Ouagadougou, 320.

[15] Maksoud SA and El Hadidi MN. (2005). The flavonoids of Balanites aegyptiaca (Balanitaceae) from Egypt. Plant Systematics and Evolution, 160(3), 153-158.

[16] Sarker SD, Bartholomew B and Nash RJ. (2000). Alkaloids from Balanites aegyptiaca. Fitoterapia, 71, $328-330$.

[17] Kamel MS. (1998). A furostanol saponin from fruits of Balanites Aegyptiaca. Photochem., 48(4), $755-757$.

[18] OECD Guideline 423 for the Testing of Chemicals, Acute Oral Toxicity - Acute Toxic Class Method. 2001, 1-14.

[19] Millogo-Rasolodimby J and Guinko S. (1996). Spontaneous woody plants for culinary purposes in Burkina Faso.B Berichte des Sonderf forschungsbereich, 268 (7), 125-133

[20] Diarra N, Togola A, Denou A, Willcox M, Daou C and Diallo D. (2016). Ethnobotanical study of food plants used during the lean season in the southern regions of Mali. Int. J. Biol. Chem. Sci., 10(1), 184-197.

[21] Bayala B, Pellicer-Rubio MT, Bassole IHN, Belemtougri R, Tamboura HH and B Malpaux B. (2011). Effects of Aqueous Extracts of Leptadenia hastata (Pers.) Decne. (Asclepediaceae) on Male Reproductive Functions Using Castrated Immature Rats. Research Journal of Medicinal Plants, 5, 180-188.

[22] Suky TMG, Parthipan B, Kingston C and Mohan VR. (2011). AntiInflammatory Activity of Aerial part of Balanites aegyptiaca (L.) Del against Carrageenan induced Paw Oedema. International Journal of PharmTech Research, 3, 639-643.

[23] Rao VS, De Melo CL, Queiroz MGR, Lemos TLG, Menezes DB, Melo TS and Santos FA. (2011). Ursolic Acid, a Pentacyclic Triterpene from Sambucus australis, Prevents Abdominal Adiposity in Mice Fed a High-Fat Diet. J Med Food, 14 (11), 1375-1382.

[24] Srujana R, Mary AD and Clifton AB. (2008). Phytochemicals and regulation of the adipocyte life cycle, Journal of Nutritional Biochemistry, 19, 717-726.

[25] Chin-Lin H and Gow-Chin Y. (2007). Effects of Flavonoids and Phenolic Acids on the Inhibition of Adipogenesis in 3T3-L1 Adipocytes. J. Agric. Food Chem., 55 (21), 8.

[26] Aquino R and Pizza C. (1995). New polyoxypregnane ester derivatives from Leptadenia hastata. J Nat Prod., 58(5), 672-9.

[27] Farid H, Haslinger E, Kunert O, Wegner C and Hamburger M. (2002). New Steroidal Glycosides from Balanites aegyptiaca. HCA, 85, 1019-1026.

[28] Maclean D and Luo L. (2014). Increased ATP content/production in the hypothalamus may be a signal for energysensing of satiety: studies of the anorectic mechanism of a plant steroidal glycoside, Brain research, 10-20(1-2), $1-11$. 
[29] Uto T, Tung NH, Nakajima K, Ohta T, Oiso S, Kariyazono H and Shoyama Y. (2017). Bioactivities of Eriobotrya japonica (Thunb.) Lindl. Leaf and Its Triterpenes. J Pharmacogn Nat Prod, 3 (1), 1-9.

\section{How to cite this article}

Paré D, Hilou A, N'do JY, Guenne S and Nacoulma OG. (2019). Ethnobotanical study and effect on mice weight gain of four plants used during famine in Burkina Faso: Raphionacme daronii, Gardenia erubescens, Leptadenia hastata and Balanites aegyptiaca. World Journal of Advanced Research and Reviews, 3(2), 73-82. 